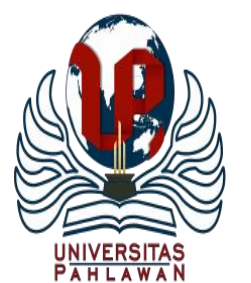

Jurnal Abdidas Volume 1 Nomor 5 Tahun 2020 Halaman 345 - 351

JURNAL ABDIDAS

Community Development Service on Educational and Health Sciences http://abdidas.org/index.php/abdidas

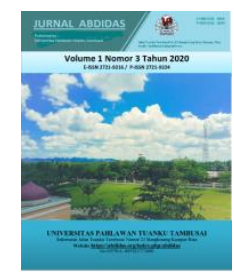

\title{
Pembuatan Cairan Desinfektan dan Bilik Disinfektan sebagai Upaya Pencegahan Virus COVID-19 di Mlajah Bangkalan Madura
}

\author{
Nikmah Suryandari ${ }^{1}$, Saqif Haidarravy ${ }^{2}$ \\ Universitas Trunojoyo Madura, Indonesia ${ }^{1,2}$ \\ E-mail : nikmahsuryandari@ trunojoyo.ac.id ${ }^{1} \underline{\text { saqif@ gmail.com }}{ }^{2}$
}

\begin{abstract}
Abstrak
Pada awal Maret 2020 pandemi virus COVID-19 mengejutkan seluruh warga dunia. Sebagai salah satu upaya praktis dalam mencegah penyebaran virus ini adalah dengan menerapkan pola hidup sehat. Pola hidup sehat dapat dilakukan melalui pembuatan cairan desinfektan dan bilik desinfektan. Kegiatan ini dilakukan dalam pengabdian masyarakat di wilayah Desa Mlajah Kecamatan Bangkalan Kabupaten Bangkalan Jawa Timur. Kegiatan dilakukan melalui beberapa tahapan, yaitu perencanaan, pra-survei, penyusunan instrumen pengabdian, dan pelaksanaan kegiatan pengabdian. Kegiatan ini dilakukan sebagai upaya nyata kegiatan yang diharapkan mampu memutus mata rantai penyebaran COVID-19 di Bangkalan Jawa Timur. Target dan capaian kegiatan ini adalah peningkatan pengetahuan dan kesadaran masyarakat sebagai salah satu upaya memutus mata rantai penyebaran COVID-19. Dalam kegiatan ini juga meningkatkan kesadaran masyarakat mengenai bahaya virus COVID-19 dan secara disiplin menerapkan protokol kesehatan peningkatan pengetahuan warga masyarakat mengenai virus COVID-19 dan upaya pencegahannya diharapkan memberi kontribusi positif dalam mendukung tugas pemerintah bidang kesehatan.
\end{abstract}

Kata kunci: COVID-19, desinfektan, bilik desinfektan, Mlajah Bangkalan

\begin{abstract}
In early March 2020 the COVID 19 pandemic shocked all citizens of the world. As one of the practical efforts to prevent the spread of this virus is by adopting a healthy lifestyle. A healthy lifestyle can be done through the manufacture of disinfectant fluids and disinfectant booths. This activity is carried out in community service in the area of Mlajah Village, Bangkalan District, Bangkalan Regency, East Java. The activity is carried out in several stages, namely planning, pre-survey, preparation of service instruments, and implementation of service activities. This activity was carried out as a concrete effort for activities that are expected to be able to break the chain of the spread of COVID 19 in Bangkalan, East Java. The target and achievement of this activity is to increase public knowledge and awareness as an effort to break the chain of spreading COVID 19. In this activity, it also increases public awareness about the dangers of the COVID 19 virus and disciplines implementing health protocols Increasing public knowledge about the COVID 19 virus and efforts prevention is expected to make a positive contribution in supporting the government's work in the health sector.
\end{abstract}

Keywords: COVID-19, disinfectant, disinfectant booth, Mlajah Bangkalan

Copyright (c) 2020 Nikmah Suryandari, Saqif Haidarravy

$\triangle$ Corresponding author

Address : Prodi Ilmu Komunikasi FISIB UTM

ISSN 2721- 9224 (Media Cetak)

Email : nikmahsuryandari@trunojoyo.ac.id

ISSN 2721- 9216 (Media Online)

Phone : 081803443344

DOI : https://doi.org/10.31004/abdidas.v1i5.70 


\section{PENDAHULUAN}

Pada awal Maret 2020, dunia dikejutkan oleh munculnya pandemi COVID 19 yang merubah hampir seluruh sistem tatanan kehidupan manusia. Organisasi Kesehatan dunia (WHO) secara resmi menyatakan bahwa COVID 19 menjadi pandemik global dan meminta ke semua negara untuk melakukan upaya maksimal dalam guna membatasi penyebaran maupun jumlah kasus COVID 19.

Laporan WHO pada 6 April 2020 menyebutkan bahwa pasien dengan infeksi COVID-19 sudah mencapai 1.210.956 jiwa pada 205 negara dengan angka kematian 5,6\%. Kementerian Kesehatan Republik Indonesia pertama kali melaporkan kasus COVID-19 pada 2 Maret 2020 yang dimulai dari 2 kasus di Jawa Barat. Hingga pada tanggal 7 April 2020, Kementerian Kesehatan Republik Indonesia melaporkan infeksi COVID-19 mencapai 2.738 orang dengan angka kematian 8,1\% (Adiputra, 2020). Sementara data dari Harirah (Ekp et al., 2020) bila dilihat dari peta persebaran COVID-19 di Indonesia, kasus positif telah tersebar pada 34 provinsi di Indonesia. DKI Jakarta masih sebagai provinsi terbanyak kasus positif COVID 19 dengan jumlah 6.236 kasus. Sementara itu, kasus positif diluar pulau Jawa, seperti Sulawesi Selatan juga tercatat memiliki jumlah kasus positif yang tinggi yaitu 1.101 kasus. Ini membuktikan bahwa kawasan episentrum penularan tidak lagi berada di pulau jawa saja.

Dilihat dari peta persebaran COVID-19 di Indonesia, kasus positif telah tersebar pada 34 provinsi di Indonesia (CNN, 2020). DKI Jakarta masih sebagai provinsi terbanyak kasus positif COVID 19 dengan jumlah 6.236 kasus. Sementara itu, kasus positif diluar pulau Jawa, seperti Sulawesi Selatan juga tercatat memiliki jumlah kasus positif yang tinggi yaitu 1.101 kasus. Ini membuktikan bahwa kawasan episentrum penularan tidak lagi berada di Pulau Jawa saja.

Jumlah penderita COVID 19 yang mengalami peningkatan disebabkan oleh banyak faktor. Salah satunya adalah kurangnya kesadaran masyarakat mengenai perilaku kesehatan secara keseluruhan. Fenomena seperti ini sebenarnya tidak terlalu mengherankan mengingat kualitas literasi kesehatan negeri ini cenderung rendah. Saat instrumen untuk mengukur tingkat literasi kesehatan di Indonesia secara menyeluruh masih sangat rendah (Hadisiwi, 2016). Penelitian di Kota Semarang yang menyebutkan sebagian besar masyarakatnya memiliki perilaku kesehatan yang tidak memadai akibat rendahnya pengetahuan tentang kesehatan (Mubarokah, 2019). Sementara itu, riset di Universitas Indonesia menunjukkan bahwa hanya mahasiswa kesehatan yang memiliki tingkat literasi kesehatan yang cukup baik dibandingkan mahasiswa non kesehatan (Lestari, 2017).

Sejak pengumuman resmi mengenai penanganan dan pencegahan penyebaran virus COVID 19, muncul beragam kebijakan pemerintah seperti protokol kesehatan. Hal ini merupakan perwujudan bahwa pemerintah hadir dan siap menghadapi COVID 19. Protokol tersebut tidak hanya berisi panduan bagaimana penanganan penderita yang telah terinfeksi COVID 19, dan menghindari penularan secara angsung; tetapi juga 
memberi panduan disinfeksi di tempat umum sebagai upaya pencegahan penularan di tempat umum (Gugus Tugas Percepatan Penanganan COVID-19 Indonesia, n.d.).

Berdasarkan definisinya, disinfeksi
merupakan proses pengurangan jumlah
mikroorganisme ke tingkat bahaya lebih rendah
pada permukaan yang terindikasi kontaminasi oleh
mikroorganisme dengan menggunakan bahan
(disinfektan) yang dapat berfungsi untuk
mengendalikan, mencegah, bahkan meng-
hancurkan microorganism berbahaya
(Occupational Safety and Health Branch., 2007).

Corona virus dapat menyebar melalui berbagai media. Manusia sebagai salah satu sumber transmisi penyebaran virus utama melalui tetesan atau butiran partikel akibat batuk atau bersin. Selain itu, media lain seperti logam, kertas, kaca bisa menjadi tempat untuk transmisi virus corona.

COVID-19 akan inaktif jika terkena sinar ultraviolet dan suhu tinggi serta disinfektan yang bersifat lipofil (larut lemak) yaitu: eter, etanol, klorin, asam peroksi asetat dan kloroform. COVID-19 akan berkembang biak dalam tubuh manusia dalam masa inkubasi 3-7 hari bahkan hingga 14 hari. Sepanjang daya tahan tubuh manusia yang terinfeksi cukup, maka COVID-19 akan mati dengan sendirinya (self limiting disease).

Salah satu cara untuk mencegah penularan dan penyebarannya adalah dengan senantiasa menjaga kebersihan dari diri dan lingkungan. Menjaga kebersihan diri dan lingkungan dapat dilakukan dengan cara menggunakan antiseptik dan desinfektan. Antiseptik merupakan zat yang dapat menghambat pertumbuhan dan perkembangan mikroorganisme tanpa harus membunuh mikroorganisme tersebut di jaringan hidup. Antiseptik biasanya mengandung alkohol, chlorhexidine, dan anilides. Desinfektan merupakan zat yang dapat membunuh patogen di lingkungan. Desinfektan biasanya mengandung glutaraldehid dan formaldehid. Penggunaan zat-zat tersebut sebelumnya lebih menjadi tanggungjawab tenaga medis, namun untuk sekarang penggunaan zat-zat tersebut dapat digunakan tidak hanya di rumah sakit, namun di rumah pun akan sering digunakan (Larasati et al., 2020).

Berdasarkan beberapa penelitian yang dilakukan, terdapat hasil yang menunjukkan bahwa efektifitas penggunaan antiseptik dan desinfektan dalam membunuh virus memang ada. Namun jika hal ini tidak diikuti dengan pembatasan jarak antara penderita, pembawa, maka penularan tetap dapat terjadi dan justru bertambah. Perilaku individu maupun protokol kebersihan tiap individu sangat penting dalam mengendalikan laju persebaran virus COVID 19 ini, seperti pembatasan jarak sosial (social distancing), isolasi mandiri (Larasati et al., 2020).

Menurut informasi yang dikutip dari Republika, data per 19 Mei 2020, di Madura ada 55 warga yang dinyatakan positif COVID 19. Data ini merujuk dari Tim Satgas COVID 19 Pamekasan. Dari angka tersebut jumlah pasien positif terbanyak berasal dari Bangkalan sebanyak 26 orang, disusul Pamekasan 12 orang Sampang 11 orang dan Sumenep 6 orang. Pasien dalam Pengawasan di Madura semuanya sebanyak 60 
orang. Perinciannya di Bangkalan 13 orang, Sampang 10 orang, Pamekasan 34 orang dan Sumenep sebanyak 3 orang. Sementara orang dalam pemantauan (ODP) di Madura terdata sebanyak 2.063 orang dperincian di Kabupaten Bangkalan sebanyak 835 orang, Sampang 452 orang, Pamekasan 451 orang dan Sumenep sebanyak 323 orang. (https://republika.co.id/berita/q9wk61330/cegahcovid19-terapkan-pola-hidup-sehat)

Berdasarkan data-data diatas, dirumuskan permasalahan pada kegiatan pengabdian pada masyarakat ini adalah bagaimana cara mencegah penyebaran COVID-19 melalui pembuatan disinfektan dan bilik disinfektan dalam meningkatkan kesadaran masyarakat di Desa Mlajah Bangkalan Kabupaten Bangkalan?

Tujuan dari kegiatan pengabdian pada masyarakat ini adalah (1) memberikan pengetahuan dan pemahaman mengenai pentingnya berbagai upaya pencegahan penularan virus COVID 19, (2) memberikan wawasan mengenai dampak buruk akibat pandemik virus COVID 19, (3) memberikan pengetahuan dan pemahaman mengenai cara pembuatan cairan disinfektan dan bilik disinfektan di masa pandemik, (4) memberikan pengetahuan dan pemahaman tentang solusi pencegahan dan penularan virus COVID 19 melalui kegiatan yang sesuai dengan protokol kesehatan.

Kegiatan ini diharapkan akan memberikan manfaat langsung bagi warga masyarakat di wilayah sasaran mengenai pentingnya pola hidup bersih sehat sebagai salah satu upaya pencegahan dan penyebaran virus COVID 19. Kegiatan dilakukan di Desa Mlajah Kecamatan Bangkalan, Kabupaten Bangkalan Jawa Timur.

\section{METODE}

Metode kegiatan pengabdian masyarakat yang digunakan dalam menyelesaikan masalah adalah melalui metode pendidikan masyarakat. Kegiatan pengabdian pada masyarakat dilakukan melalui penyuluhan dan sosialisasi pembuatan cairan desinfektan dan bilik desinfektan di daerah Kompleks Masjid Baiturrachim Kelurahan Mlajah Bangkalan.

\section{HASIL DAN PEMBAHASAN}

Kegiatan pengabdian masyarakat ini dilakukan terhadap warga masyarakat di Desa Mlajah Kecamatan Bangkalan Kabupaten Bangkalan Jawa Timur. Pelaksanaan kegiatan pengabdian pada masyarakat ini terdiri atas beberapa tahapan antara lain, yaitu perencanaan, pra-survei, penyusunan instrumen kegiatan, pelaksanaan kegiatan dan evaluasi kegiatan.

Tahap perencanaan kegiatan pengabdian pada masyarakat ini berupa identifikasi masalah di lokasi sasaran. Juga penentuan sasaran utama dari kegiatan ini yaitu warga masyarakat di wilayah di Desa Mlajah Kecamatan Bangkalan Kabupaten Bangkalan. Kegiatan perencanaan ini dilakukan untuk menggali identitas, pengetahuan dan wawasan masyarakat tentang COVID 19, desinfektan dan bilik desinfektan. Wawancara dilakukan dengan panduan instrumen cheklist. Berdasarkan informasi pada tahapan ini, akan diperoleh informasi mengenai bagaimana 
pengetahuan masyarakat tentang virus COVID 19, cairan desinfektan maupun bilik desinfektan.

Tahapan berikutnya adalah pra-survei lokasi kegiatan, dilanjutkan dengan penyusunan instrumen kegiatan pengabdian masyarakat beserta tim pelaksana. Tim pelaksana dalam kegiatan pengabdian masyarakat ini adalah dosen beserta mahasiswa peserta KKN yang ada di Desa Mlajah Mlajah Kecamatan Bangkalan Kabupaten bangkalan. Tahap berikutnya adalah penyusunan instrumen kegiatan pengabdian pada masyarakat. Instrumen disini adalah penunjang kegiatan inti dalam kegiatan pengabdian masyarakat ini. Instrumen berupa materi pelatihan, bahan-bahan yang dibutuhkan dalam kegiatan sosialisasi dan edukasi mengenai pembuatan cairan desinfektan dan bilik desinfektan di Desa Mlajah Kecamatan Bangkalan Kabupaten Bangkalan Jawa Timur.

Setelah kegiatan survei dan dan penyusunan instrumen selesai, tahapan berikutnya adalah koordinasi dan penyelesaian masalah administrasi rencana kegiatan dengan pihak-pihak terkait di lokasi kegiatan. Berhubung kegiatan dilaksanakan pada masa pandemick virus COVID 19, koordinasi dan kegiatan dilakukan secara daring, namun untuk pelaksanaan kegiatan dilaksanakan secara luring dengan tetap mematuhi protokol kesehatan yang berlaku.

Tahapan terpenting dalam kegiatan ini adalah pelaksanaan pembuatan desinfektan dan bilik desinfektan. Pembuatan cairan desinfektan dipandang sebagai langkah penting dalam upaya pencegahan dan penyebaran virus COVID 19. Berdasarkan istilah WHO, antiseptik adalah salah satu jenis disinfektan yang menghancurkan atau menghambat mikroorganisme pada jaringan hidup tanpa mengakibatkan cidera. Contoh yang termasuk dalam klasifikasi di atas yaitu Polyvidone Iodine, Chlorhexidine, dan alcohol. Sedangkan, disinfektan berfungsi untuk menghancurkan dan menghambat mikroorganisme patogen pada keadaan vegetatif. Contoh yang termasuk dalam klasifikasi di atas yaitu Chlorine dan Etanol (Kelompok 18, 2020).

Karena kondisi masih dalam suasana pandemik COVID 19, cara yang digunakan dalam kegiatan pengabdian masyarakat sangat mempertimbangkan faktor kesehatan. Hal ini dilakukan dengan mematuhi secara ketat protokol kesehatan saat berinteraksi dengan masyarakat sasaran. Kelomopk sasaran kegiatan ini ada di Desa Mlajah Kecamatan Bangkalan Kabupaten Bangkalan. Upaya peningkatan kesadaran tentang pembuatan desinfektan dan bilik desinfektan sebagai upaya untuk mengurangi risiko penyebaran virus, pentingnya menjaga kesehatan untuk memutus mata rantai penyebaran virus COVID 19.

Tim kegiatan pengabdian pada masyarakat beserta dengan masyarakat desa membuat disinfektan, bilik desinfektan dibuat dari bahan sederhana, namun tetap memperhatikan komposisi yang tepat. Berdasarkan pada data pada tahapan perencanaan, diperlukan bahan yang mudah ditemui di pasaran yang beredar di masyarakat dan juga yang sesuai dengan rekomendasi dari WHO yaitu: 1) wipol dengan takaran 2 sendok makan per 1 liter air, 2) supersol dengan takaran 2 sendok makan per 1 liter air, 3) air Mineral dengan 1 tutup botol per 5 liter air, 4) besi yang memiliki panjang 
DOI : https://doi.org/10.31004/abdidas.v1i5.70

$120 \mathrm{~cm}$ dengan tinggi 2 meter, 5) plastik mika yang memiliki panjang sama dengan panjang besi dengan tinggi yang sama, 6) saklar, 7). 6 unit sprey, 8) selang berukuran 8 hingga $9 \mathrm{ml}$ yang berfungsi untuk menyalurkan cairan disinfektan keluar melalui sprey, 9) galon dengan netto 19 liter yang berfungsi sebagai daya tampung cairan disinfektan (Kelompok 18, 2020).

Tujuan dari pembuatan bilik desinfektan ini adalah untuk membunuh mikroorganisme yang menempel di badan atau di pakaian seseorang secara langsung, sedangkan pembuatan cairan disinfektan tujuan cairan desinfektan hampir sama dengan pembuatan bilik desinfektan hanya saja yang membedakan adalah penempatan penyemprotannya tersebut (Kelompok 18, 2020).

Tahap pelaksanaan pendampingan meliputi sosialisasi, demonstrasi (praktek) pembuatan desinfektan dan bilik desinfektan (Gambar 1,2,3) dan pemberian bantuan alat-alat tersebut. Kegiatan dilakukan dengan cara memberikan informasi kepada para warga masyarakat Desa Mlajah Kecamatan Bangkalan Kabupaten bangkalan Informasi yang disampaikan berupa kondisi terkini pandemik virus COVID 19, cara pencegahan dan penyebaran virus COVID 19. Diantaranya melalui pola hidup bersih dan sehat, sering cuci tangan, menggunakan masker dan disiplin menerapkan protokol kesehatan.

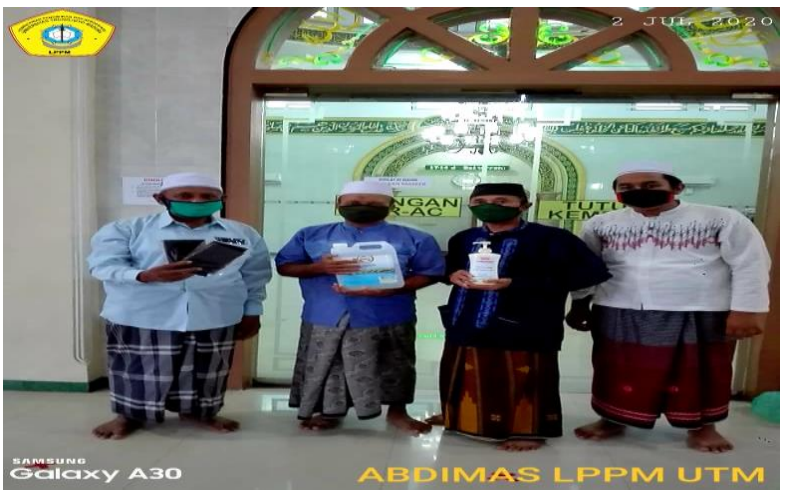

Gambar 1. Sosialisasi dan praktek pembuatan desinfektan

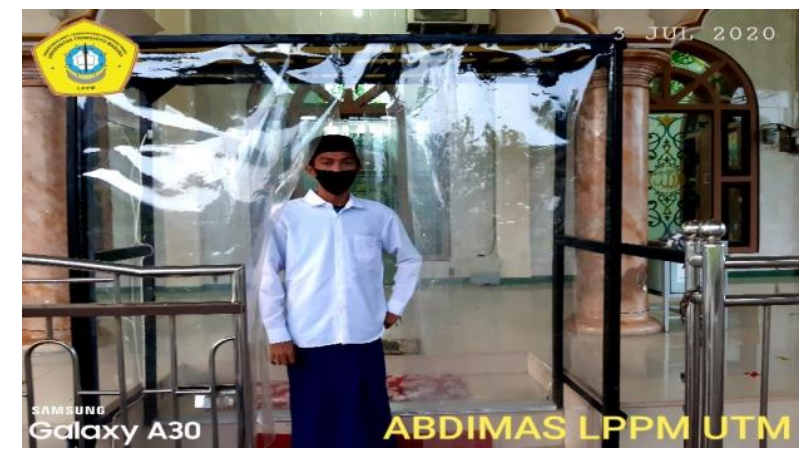

Gambar 2: Bilik desinfektan di Desa Mlajah Kecamatan Bangkalan Kabupaten Bangkalan

Tahapan sosialisasi dan edukasi mengenai pembuatan cairan desinfektan dan bilik desinfektan ini dilakukan oleh tim pengabdian pada masyarakat beserta warga, serta Takmir Masjid Baiturochim Desa Mlajah Kecamatan Bangkalan.

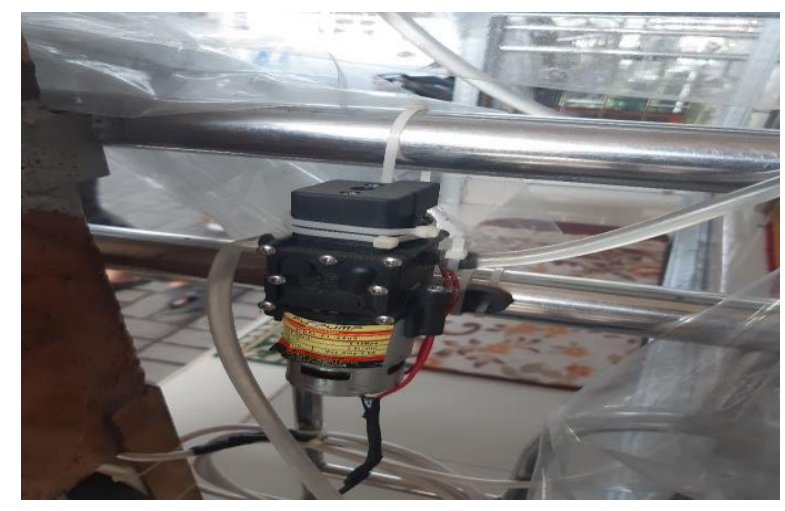

Gambar 3: Peralatan pembuatan bilik desinfektan 


\section{SIMPULAN}

Kegiatan pengabdian masyarakat dilaksakan pada warga Desa Mlajah Kecamatan Bangkalan Kabupaten Bangkalan Jawa Timur Kegiatan dilakukan dengan cara edukasi, sosialisasi, demonstrasi (praktek) pembuatan cairan desinfektan dan bilik desinfektan dalam rangka mencegah dan mengurangi penyebaran virus COVID 19. Dalam pelaksanaan kegiatan pengabdian masyarakat pembuatan cairan desinfektan dan bilik desinfektan ini, dilakukan melalui penyuluhan kepada masyarakat (dengan tetap memperhatikan protokol kesehatan) seperti cuci tangan dengan sabun, penggunaan masker, penerapan social distancing. Kegiatan ini dilakukan sebagai upaya nyata kegiatan yang diharapkan mampu memutus mata rantai penyebaran COVID 19 di Bangkalan Jawa Timur.

\section{UCAPAN TERIMA KASIH}

Ucapan terima kasih penulis tujukan kepada pihak Lembaga Penelitian dan Pengabdian Pada Masyarakat (LPPM) Universitas Trunojoyo Madura (UTM) yang telah mendanai dan mendukung dalam kegiatan pengabdian pada masyarakat ini.

\section{DAFTAR PUSTAKA}

Adiputra, P. A. T. (2020). Dampak Pandemi COVID-19 pada Pelayanan Pasien Kanker di Rumah Sakit Tersier di Indonesia: Serial Kasus. JBN (Jurnal Bedah Nasional). https://doi.org/10.24843/jbn.2020.v04.is01.p 07

Ekp, A. G., Unsyiah, F. E. B., Darussalam, K., Aceh, B., Covid, P., \& Indonesia, D. I. (2020). Merespon Nalar Kebijakan Negara
Dalam Menangani Pandemi Covid 19 Di Indonesia. Jurnal Ekonomi Dan Kebijakan Publik Indonesia, 7(1), 36-53. https://doi.org/10.24815/ekapi.v7i1.17370

Gugus Tugas Percepatan Penanganan COVID-19 Indonesia. (n.d.). https://covid19.go.id/

Hadisiwi. (2016). Literasi Kesehatan Masyarakat Dalam Menopang Pembangunan Kesehatan di Indonesia. (Prosiding Seminar Nasional Komunikasi.).

Kelompok 18. (2020). Laporan KKN Genap 20192010.

Larasati, A. L., Gozali, D., \& Haribowo, C. (2020). Penggunaan Desinfektan dan Antiseptik Pada Pencegahan Penularan Covid-19 di Masyarakat. Majalah Farmasetika, 5(3), 137-145. https://doi.org/10.24198/mfarmasetika.v5i3.2 7066

Lestari. (2017). The higher level of health literacy among health students compared with nonhealth students . UI Proceedings on Health and Medicine.

Mubarokah. (2019). Health Literacy and Health Behavior in the Rural Areas". . . . . The 3rd International Meeting of Public Health and The 1st Young Scholar Symposium on Public Health. KnE Life Sciences, 8-16. https://doi.org/10.18502/kls.v4i10.

Occupational Safety and Health Branch. (2007). 